Article

\title{
Governing Disasters: Embracing Human Rights in a Multi-Level, Multi-Duty Bearer, Disaster Governance Landscape
}

\author{
Lottie Lane $^{1, *}$ and Marlies Hesselman ${ }^{2}$ \\ ${ }^{1}$ Groningen Centre for Law and Governance, University of Groningen, 9712 CP Groningen, The Netherlands; \\ E-Mail: c.l.lane@rug.nl \\ 2 Department of International Law, University of Groningen, 9712 CP Groningen, The Netherlands; \\ E-Mail:m.m.e.hesselman@rug.nl \\ * Corresponding author
}

Submitted: 31 January 2017 | Accepted: 13 March 2017 | Published: 12 May 2017

\begin{abstract}
International and national disaster governance faces multiple challenges given the large variety and amounts of resources, skills and expertise that adequate disaster response commands. Moreover, disasters do not necessarily respect territorial boundaries, or may overwhelm the capacity of any one nation. They may therefore need a truly collective, joint, or even global effort to be overcome. Not seldom, reducing disaster risks and responding to disasters as they occur requires a sustained, concerted and coordinated effort of a broad range of actors, both public and private, acting nationally and internationally, and across the full 'disaster cycle'. Unfortunately, disaster governance is commonly characterized as patchy, fragmented and inadequate, leading to essential protection gaps for affected communities. In order to strengthen disaster governance, this article first aims to further conceptualize the practice and challenges of 'disaster governance', mostly through the lens of 'Multi-Level Governance'. Secondly, it proposes that disaster governance will greatly benefit from relevant actors more firmly embracing human rights-based approaches, particularly in the context of so-called, emerging 'multi-duty bearer human rights regimes'.
\end{abstract}

\section{Keywords}

disasters; human rights; human rights-based approaches; multi-duty bearer human rights regimes; multi-level governance; non-state actors

Issue

This article is part of a multidisciplinary issue of Politics and Governance, edited by Naim Kapucu (University of Central Florida, USA).

(C) 2017 by the authors; licensee Cogitatio (Lisbon, Portugal). This article is licensed under a Creative Commons Attribution 4.0 International License (CC BY).

\section{Introduction}

Over the past two decades, the huge and protracted impacts on human lives caused by disasters have revealed a dire need for improved national and international protection frameworks, and essentially for better disaster governance. Yet, research into existing governance frameworks typically shows that disaster governance architectures are highly dynamic, complex, multi-level, multiactor, and fragmented and patchy in nature. Particularly, disaster governance takes place amongst a broad range of public and private actors, at various levels (from the local to the global) and involves various types of activities, in various phases of disaster management (Fisher, 2007; Gall, Cutter, \& Nguyen, 2014, p. 4; International Federation of Red Cross and Red Crescent Societies [IRFC], 2000, 2005, 2007, pp. 24, 151; Tierney, 2012).

In recent years, several international initiatives have sought to improve international and domestic disaster governance, in particular by clarifying 'legal standards, procedures, rights and duties', or by attempting to 'pull together the disparate threads of existing law' and to 
'expand and develop the law in new ways'; indeed, especially in international law, various initiatives have emerged to develop or clarify the law or to improve the coordination and synthesis of different regimes (see IFRC, 2000, p. 145, 2007; Inter-Agency Standing Committee [IASC], 2011; International Law Commission [ILC], 2016; Sphere Project, 2011).

The outcome of one important initiative, the 'International Disaster Response Law' Programme of the International Federation of the Red Cross (IFRC, 2007), affirmed the lingering image that disaster governance indeed remains mostly carried out through an amalgam of loosely related regulatory instruments, policies and processes, with a 'yawning gap' at its core (IFRC, 2000, p. 145, 2007; Fisher, 2007). In fact, a single glance at the numerous search categories that organize the IFRC's Disaster Law Database-currently containing over 1,300 national, regional and international instruments-shows that instruments pertain to different:

- Types of disasters (e.g. hydrological, meteorological, technological, environmental disasters);

- Actors involved (e.g. affected states, assisting states, transit states, inter-governmental organisations, non-governmental organizations, the private sector, individuals);

- Sectors (e.g. telecom, food, water, health, housing);

- Activities (e.g. rescue, relief, recovery, risk reduction);

- Or disagree on key terms (e.g. risk, vulnerability, humanitarian assistance, preparedness).

This has only been partially improved by other recent initiatives - such as the International Law Commission's Draft Articles on the Protection of Persons in the Event of Disasters, or the new Sendai Framework on Disaster Risk Reduction (DRR) (ILC, 2016; United Nations Office for Disaster Risk Reduction [UNISDR], 2015b)-for these instruments still focus predominantly on certain actors or certain topics (e.g. on states, disaster relief, or DRR).

The most important problem of such fragmented and patchy approaches is an unwanted duplication of efforts or serious gaps in protection, including delays in the delivery of crucial, life-saving goods and services to disaster victims, or poor coordination of activities between pre-, post- and disaster-proper phases (Fisher, 2007; IFRC, 2007; Jones, Oven, Manyena, \& Aryal, 2014).

In response to the current inadequacy of disaster governance, the main purpose of this article is twofold. First, it aims to sketch in greater conceptual detail the various dimensions and challenges of governing disasters (Section 2). In particular, we use the Type I and Type II typology of 'Multi-Level Governance' (MLG) as proposed by Hooghe and Marks (2004) as a general framework (Section 3). The purpose of embedding this article in MLGliterature is not necessarily to 'test', reflect on or add to MLG-theory as such, but rather to use MLG as oth- ers have done: as a useful heuristic device to understand how disaster governance is 'arranged today in a way that [is] easy to grasp' and what challenges might arise from such arrangements (Stephenson, 2013, p. 818, emphasis removed). In fact, we are aware that MLG-literature has been criticized for its lack of engagement with explanations of causality, or with what drives MLG-regimes to come about in the first place (Stephenson, 2013). While we acknowledge such concerns and the importance of asking these questions, certainly as a matter of political science research, we also emphasize immediately that, as principally international legal scholars, we intend to use MLG predominantly in its more descriptive form as a way of understanding which levels or actors may be involved in disaster governance and how their activities may overlap or relate to each other.

On the basis of this conceptual MLG framework, we embark on the second part of our article, which is an inquiry into the role of international human rights law (IHRL) and human rights-based approaches (HRBAs) for improving disaster governance. Here, the article will actually argue that HRBAs may be able to remedy some central criticisms of MLG regimes, notably, the difficulty of (al)locating material responsibilities among many different actors and levels and, above all, ensuring an adequate measure of answerability and accountability to affected populations in such complex regimes.

Indeed, IHRL must by now be considered a cornerstone, if not a key touchstone, for disaster governance activity. IHRL protects a broad range of disaster-relevant rights, such as the human rights to water, food, shelter, medical care, adequate housing, social security, insurance, information, or the protection of life, homes, property and physical integrity, in all phases of disaster management (for a comprehensive analysis of how IHRL applies to disaster management, see Cubie \& Hesselman, 2015; Hesselman, 2013). Recent key international standard-setting initiatives on disaster governance affirm the importance of human rights, for example when they state that '[p]ersons affected by disasters are entitled to the respect for and protection of their human rights in accordance with international law' (ILC, 2016, Draft Article 5, or IASC, 2011; UNISDR, 2015b, Principle 19; Sphere Project, 2011; United Nations Human Rights Council [UNHRC], 2015). In our view, IHRL is an indispensable, universal reference point for all actors involved in disaster governance, because its relevant protective standards can help improve the design of disaster programmes, processes and activities and also provide affected communities with pertinent yardsticks against which to assess relevant actors' behavior in the completion of their disaster-related activities. The application of IHRL standards through HRBAs in particular (as explained in Section 4) will assist in improving the overall accountability of all relevant actors as well as the allocation and distribution of responsibility among diverse actors that undergirds the possibilities for improved accountability in the first place. The latter is further underscored by our 
analysis of the present, progressive articulation of international human rights responsibilities for non-state actors in IHRL, and the emergence of so-called 'multi-duty bearer human rights regimes' (Section 4.2). At the same time, these multi-duty bearer regimes are also still developing, and they may learn from the insights gathered from the MLG analysis in Section 3.

\section{Disaster Governance}

Recently, the term 'disaster governance' has been defined as:

the interrelated sets of norms, organisational and institutional actors, and practices (spanning predisaster, trans-disaster, and post-disaster periods) that are designed to reduce the impacts and losses associated with disasters....Disaster governance goes beyond governmental settings, powers, processes and tools by encouraging collective actions through the engagement of all stakeholders...operating at all scales-from local to global. (Gall et al., 2014, p. 4; Tierney, 2012)

Arguably, the term 'disaster governance' is closely related to, but not entirely synonymous with, the more familiar term 'disaster risk governance'. The latter term is linked to the field of DRR and mostly focuses actors' attention on the reduction and avoidance of disasterrelated risks in a broad sense-and away from the narrower management of emergency disaster relief (see definition of 'disaster risk governance' and DRR by UNISDR (2015a, 2017).

We do not necessarily prejudice the term 'disaster governance' over 'disaster risk governance'. However, we affirm the importance-as also stressed by the definition above-of a holistic, integrated vision of the activities required in all phases of disasters, including disaster risk reduction, preparedness and prevention in pre-disaster phases, emergency response, relief and search and rescue activity in disaster-proper phases, and (early) recovery and reconstruction in post-disaster phases. Such a holistic approach is in line with current disaster management literature, which commonly embraces the concept of the 'disaster cycle' (de Lourdes Melo Zurita, Cook, Harms, \& March 2015, p. 386; Farber, 2014; Hesselman, 2013; IASC, 2011, p. 2). At the same time, the UNISDR (2015a) recently critiqued the limited definition that many actors attach to the term 'disaster risk management/governance', in the sense that actors seem to focus mostly on mitigating or preparing for exogenous risks and hazards (e.g. floods, a typhoon, earthquake or mud-slide) or try to improve preparedness for response and relief, instead of also addressing dire endogenous, structural risk factors in society, such as poor financial stability, under-sourced local governments, poverty in the population, or pre-existing social conflict (UNISDR, 2015a, pp. 128-129). UNISDR (2015a, p. 129) even submits that 'disaster management cycle'-based governance regimes, carried out through specialized disaster risk management sectors, may have reached their limit, because this sector is starting to share an 'increasingly crowded space with the climate change sector, finance and planning ministries, the private sector and city governments'. Moreover, 'managing risks cannot be separated from the broader governance of social and economic development', however, a new governance paradigm has yet to emerge' (UNISDR, 2015a, p. 129).

We posit here that, also from this broader governance perspective, IHRL provides a valuable integrative governance framework, as it is specifically applicable to all phases of the disaster cycle and to structural underlying risk factors and other fields, such as poverty reduction, discrimination, social exclusion, or climate change.

Finally, before further considering the characteristics and challenges of disaster governance through a lens of MLG, it is useful to point out that a salient challenge of governing 'disasters' continues to be the lack of a single, authoritative definition of 'disasters'. For example, (the causes of) disasters in various legal instruments are identified as natural, man-made, technological, slow-onset (e.g. desertification, drought, salinification) or suddenonset (e.g. hurricanes, earthquakes, oil spills), and in some cases include terrorism or armed conflict (see generally ILC, 2016; Telesetksy, 2015; Tierney, 2012). Naturally, in order to understand the relevance or applicability of certain governance regimes to any particular event or any set of risk factors, a further understanding of what a disaster (risk) might entail is important.

\section{Multi-Level (Disaster) Governance}

\section{1. (Disaster) Governance without or beyond States}

The general term 'governance' can mean different things and has attracted different definitions in literature depending on the context. For example, governance has been defined as 'the attempts of governments or other actors to steer communities, whole countries, or even groups of countries in the pursuit of collective goals' (Bell \& Hindmoor, 2009, p. 1), or as 'a process whereby societies or organizations make their important decisions, determine whom they involve in the process and how they render account' (Graham, Amos, \& Plumptre, 2003, p. 1).

It is a popular notion (both within governance literature itself and literature pertaining to transnational policymaking/global public policy, e.g. Stone \& Ladi, 2015), that governance does not equal government. The definition of disaster governance provided above clearly considers 'governance' to go 'beyond governmental settings, powers, processes and tools by encouraging collective actions through the engagement of all stakeholders' (Graham et al., 2003; emphasis added). Some governance literature supports that governance may even take place without government (e.g. Jones et al., 2014, p. 80; Peters 
\& Pierre, 1998, pp. 223-243; Rhodes, 2006; Rosenau \& Czempiel, 1992).

For disaster settings, governance 'beyond' or 'without' governments is certainly of interest both nationally and internationally. First, hazardous situations will in many cases (temporarily) overwhelm state authorities, especially in countries with scarce resources. Moreover, affected states may lack the necessary capacity to prevent or respond to disasters altogether, or may not be in a position to act as first responders (e.g. see Tierney, 2012, p. 351). Aldrich and Meyer (2015, pp. 255-256) also note that in many disaster settings, individuals such as neighbors and family members will be the first actors to respond and 'provide immediate lifesaving assistance', and that communities with strong 'social capital networks' tend to rely on formal institutions to a lesser degree, and have a better chance of adequately responding to and (swiftly) recovering from disasters (see Aldrich \& Meyer, 2015, pp. 257-258). While a full consideration of what constitute 'social capital networks' is beyond the scope of this paper, the argument is that high levels of political, civic, social, religious or family cohesion bolster disaster resilience due to mutual support in communities (see Aldrich \& Meyer, 2015). In circumstances of governance without or beyond government, it is nevertheless always important to understand which action nonstate actors may or must take, and whether and which (direct) responsibilities might exist for various actors. Importantly, which (types of) responsibilities (still) exist for state actors, in a residual or complementary manner?

On the complexity of locating responsibility when private actors are involved, de Lourdes Melo Zurita et al. (2015) have pointed out in relation to the involvement of NGOs in Australian disaster response and recovery, for example, that local NGOs originally focused on 'filling the 'gaps' in services not provided through formal government channels', but that they now increasingly work in close relation with higher-level government, that funds and commissions NGO activity. A key question the authors identify is whether closer alignment of NGO activity with 'governmental disaster management objectives' actually hampers the unique role of NGOs in 'identifying and filling government design gaps' and providing greater protection to the public? Particularly, has an actual, unique responsibility for non-state actors themselves been substituted by a devolution of state functions to local actors in this instance (de Lourdes Melo Zurita et al., 2015, p. 392)?

Secondly, the scale and complexity of some disasters, and their often exceptionally broad and prolonged impacts, normally also mean that disasters command skills and resources at a scale and diversity falling outside the scope of any one actor's capacities and expertise, certainly of (poor) affected states (Tierney, 2012, p. 344). Governing disasters may thus be a truly joint, societal and international effort in some respects. This is clear from the fact that in many cases, international assistance is needed. Suggestions that governments may be- come entirely absent from (disaster) governance should be viewed with caution, and seem misleading for several reasons. First, it is commonly accepted-certainly as a matter of international law - that states bear the primary responsibility for the 'direction, control, coordination and supervision of the distribution of disaster relief and assistance on their territories', and that states are typically best placed to assess the various risks, rights and interests at stake, and to manage and allocate available resources accordingly (ILC, 2016, Draft Article 10 and commentary; Jones et al., 2014, p. 80; UNISDR, 2015b). Moreover, IHRL also clearly views the state as the primary 'duty bearer' for the protection of individuals' human rights, including disaster victims, even if such perspectives are certainly shifting to include duties for nonstate actors as well (see Section 4; Hesselman \& Lane, 2017; United Nations Committee on Economic, Social and Cultural Rights [CteeESCR], 2000).

Those concerned with governance without or beyond the state typically observe that state authority and 'centrality' is receding in many areas of life, being replaced by non-state actors with more resources and growing decision-making power (see e.g. Jones et al., 2014, p. 79). In the disaster context, state authorities may be actively 'crowded out' or 'replaced' by non-state actors when they are not powerful enough to assert their own authority effectively or when they provide inadequate protection to the population. In such cases, the 'governance gap' left by 'weak' governments may be filled by others, including a multitude of (internationally-backed) non-governmental (humanitarian) organizations (NGOs) (Jones et al., 2014). Tierney recalls Haiti's nick-name as the 'Republic of NGOs' when reflecting on this country's notorious lack of capacity to deal with disasters; yet, she also immediately submits that Haiti's disaster governance is not (fully) served by the hotchpotch of international NGOs, many of which crowd the country during emergency phases, but leave when the recovery period starts and in many instances lack concrete commitment or experience with the country (Tierney, 2012, p. 351). Similarly, Jones et al. (2014, p. 85) point out that in Nepal, international donors and NGOs work together to fill government gaps, and that according to some international NGOs, 'if the government's perfect there is no need of NGO[s]'. Yet, the authors also note with some concern that the Nepalese NGO sector is increasingly entrepreneurial, in that 'everyone wants to try and get involved' and get a piece of the funding pie. In this sense, the Nepalese government needs to compete for resources with these 'entrepreneurs' and may ultimately lack the support to strengthen its overall governance capacity with the help of international support.

In other situations, states themselves may actually pro-actively recognize that certain activities are simply better performed by others (e.g. more cost-effective, higher quality, in larger volumes) and/or that adequate protection of disaster victims simply commands resources that it does not possess. In these circumstances, 
states may actively choose to delegate or bestow public interest tasks or decision-making power to others 'upwards' or 'downwards' (i.e. to international or subnational governmental authorities), or 'outwards' (to national and international non-state actors) (Jones et al., 2014; Levi-Faur, 2012). In the field of disaster governance, this may include delegation, regulation, privatization, 'out-sourcing', or 'contracting-out' of particular activities such as first aid, ambulances services, fire brigade services, contingency stock management, food delivery or reconstruction of housing (e.g. see de Lourdes Melo Zurita et al., 2015, p. 392).

\subsection{Type I and Type II MLG}

Clearly, disaster governance is a multi-layered, multiactor affair. The concept of MLG may help to further characterize this governance sphere and identify challenges that it involves. The definition of MLG used throughout this paper is that offered by the so-called 'king and queen of multi-level governance', Gary Marks and Liesbet Hooghe (Stephenson, 2013, p. 818). These scholars are known for their identification of two types of MLG in particular (Bache, Bartle, \& Flinders, 2016; Bartle, Bache, \& Flinders, 2012; Marks \& Hooghe, 2004, pp. 15-17).

First, 'Type I' MLG views MLG-regimes as consisting of neatly nested, fairly 'general-purpose', territorially-based jurisdictions-i.e. at the international, national and subnational levels. In Type I MLG-regimes, individuals are viewed as situated at the bottom of a set of 'Russian dolllike' jurisdictions that each have a set of non-overlapping functions, competences and members (Marks \& Hooghe, 2004, pp. 15-17). To some extent, Type I MLG-regimes may be concerned with 'multi-level government', rather than 'multi-level governance', although by now it is accepted that within Type I 'intensified (horizontal) interactions between government and non-governmental actors' occur at various levels (Bache et al., 2016, p. 487). We would argue that in international legal scholarship there is still a tendency to think mostly in Type I MLG structures, i.e. with scholars viewing regulation as being nationally, regionally and internationally layered. At the same time, international legal scholarship is also very much concerned with the 'fragmentation' of international law in various (self-contained) specialized regimes/jurisdictions, and how this affects a unified regulatory system of international law.

From this perspective, 'Type II' MLG is of interest, since it firmly rejects the idea of 'conceiving authority in neatly defined local, regional, national, and international layers', and favors a conception of MLG-regimes as built up through a(n infinite) multitude of specialized, 'task-oriented jurisdictions', with each jurisdiction consisting of a 'specific-purpose' governance community to which actors can volunteer themselves as participants, based on their expertise and interests (Bartle et al., 2012; Hooghe \& Marks, 2003, p. 11). As usefully submitted by Marks and Hooghe (2004, referring to Ostrom \& Ostrom):
In Type II MLG, multiple, independent jurisdictions fulfill distinct functions in which citizens are not served by 'the' government, but by a variety of different public service industries....We can then think of the public sector as being composed of many public service industries including the police industry, the fire protection industry, the welfare industry, the health services industry, the transportation industry, and so on.

Type II MLG thus recognizes 'specialized jurisdictions' where public (and private) actors gather to solve particular problems, without a centralized, overarching authority in charge and capable of exhaustively setting and delegating all tasks (Marks \& Hooghe, 2004; see also Bartle et al., 2012). It is certainly possible to view 'disaster governance' as largely undertaken through independently functioning 'sector-based' jurisdictions, both nationally and internationally. May and Williams (1986) have, for example, relied on the concept of 'shared governance' when pointing out that in the US distinct (yet potentially overlapping) disaster governance tasks were distributed among different public institutions (also see Tierney, 2012). Similarly, at the international level, the UN recognized the need for greater coordination between various disaster sectors, dealing with food, health, telecom, logistics, etc., and introduced the so-called UN 'Cluster Approach' in 2005 (see Figure 1). Through this 'cluster approach' specialized international UN or nonUN organizations were designated as so-called 'cluster lead agencies', which coordinate a broad range of international and domestic actors operating with specific disaster response sectors. Simultaneously, a measure of general oversight and coordination between sectors was centralized with the UN emergency coordinator and with country teams (see Figure 1).

Overall, it can be argued that disaster governance carries characteristics of both Type I and Type II MLG. It can be considered to resemble Type I MLG because disaster management takes place at and includes regulatory activity on various 'territorial levels' -i.e. at global, regional, national and local levels-and also still relies heavily on (inter)governmental governance. Certainly, from a perspective of general international lawat the 'national/international law frontier' - the territorial, general-purpose jurisdiction of the state remains respected; international law clearly articulates that disaster governance and the protection of persons are primary 'duties' of the affected state (e.g. see ILC, 2016; UNISDR, 2015b). Even in the absence of international law, it might be difficult to argue that state authorities would be able to voluntarily 'opt-in' or 'opt-out' of any public responsibilities in the area of disaster management; there is no 'choice' to govern or 'opt-in' (or not), in the way other actors may have this choice (see de Lourdes Melo Zurita et al., 2015, p. 394; Jones et al., 2014 , p. 80). Indeed, clearly, states are generally practically involved in disaster management on their territories, and at (sub)national levels use their general regula- 


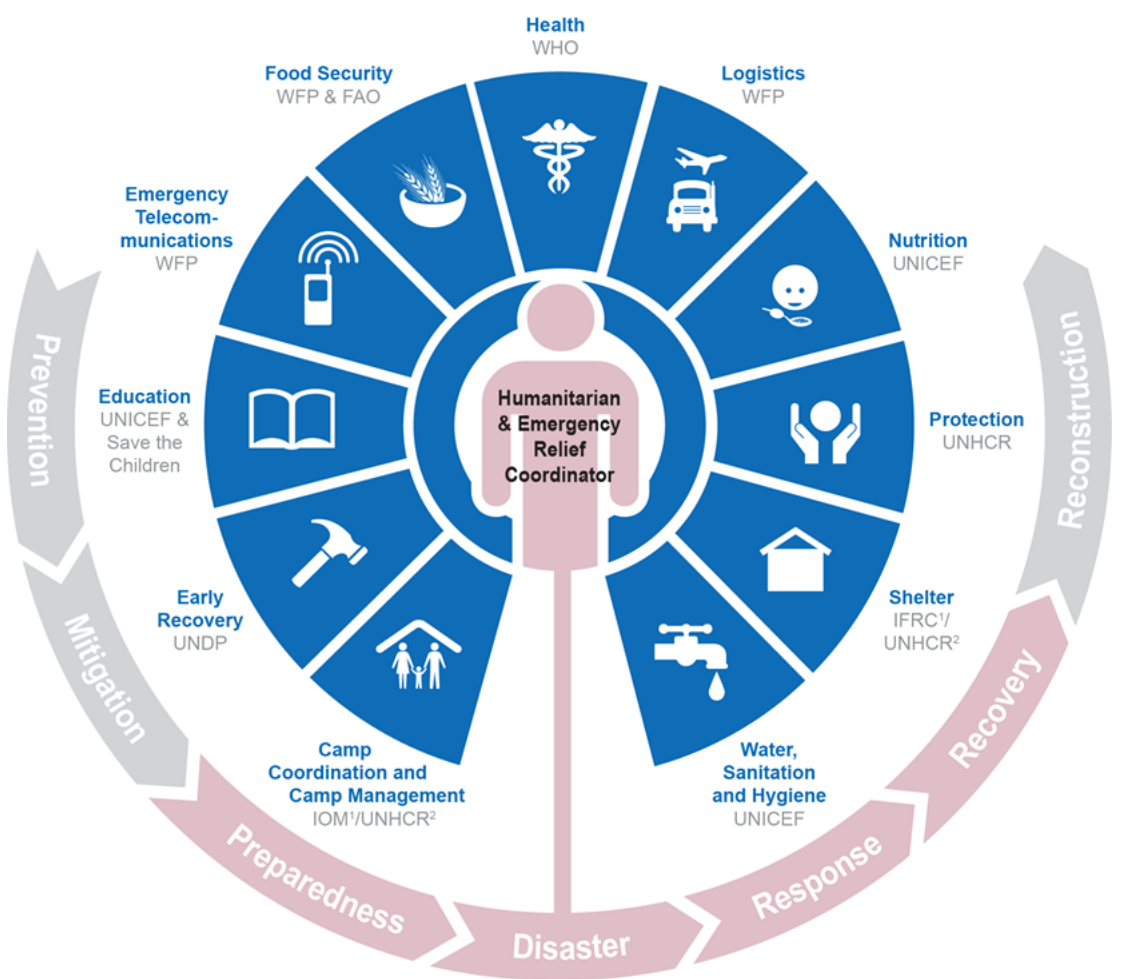

Figure 1. Cluster approach to disaster response. Source: Office for the Coordination of Humanitarian Affairs (2017).

tory powers to delegate competences and tasks in this sphere 'downwards' to lower level jurisdictions, or 'outwards' to private actors (see e.g. de Lourdes Melo Zurita et al., 2015, on Australia). When they are absent from disaster governance or there is insufficient protection in place, this is commonly viewed as a failure or weakness of the state.

At the same time, disaster governance also resembles Type II MLG, in that it is highly reliant on a 'baroque patchwork' of specialized jurisdictions involving many different resources, expertise and (non-state) actors, spanning or 'overlaying the nested pattern of Type I jurisdictions' (Marks \& Hooghe, 2004, p. 28). This is visible, for example, from the UN 'cluster approach', and the fact that disaster governance domestically is also carried out through various risk management agencies and is often organized in different sectors.

Regardless of the type of MLG-regimes, a main challenge of MLG is how to achieve a measure of coordination and unity of action and purpose in such complex governance spheres? The question is arguably even more pertinent for Type II regimes, and as the governance activity of non-state actors increases. Most importantly, how can the quality of governance be ensured, and a measure of accountability to the public for governance failures by different actors be achieved? As submitted by Bache et al. (2016, p. 489) but also by Stephenson (2013), MLG scholarship has so far shown (too) little concern for the (negative) implications of such 'complex and de-coupled governance processes' for democratic values and accountability. Papadopoulos (2007) points out that MLG's focus on 'managerial concerns of performance and efficiency' and the increased confederation of actors in diffuse, task-specific governance networks, without a clear overarching public decision-maker, means that the overall governance of important public interests (such as protecting persons in event of disasters) will become decoupled from public (democratic) control and accountability (also Stephenson, 2013, p. 826). When MLG regimes fail, for example due to the poor articulation of different (levels of) duties and responsibilities amongst different actors towards the population concerned-as seems to be the case in disaster governance-, then the question is where do affected individuals go to claim better disaster management, and on the basis of what?

The following sections posit that by embracing human rights more firmly in disaster governance, universal standards are foregrounded which all actors can jointly use to gear their activity towards the essential protection of persons. Particularly, through the notion of 'multiduty bearer human rights regimes', the implications of human rights law for non-state actors may also be better understood, and the opportunities for accountability on the basis of IHRL standards may be improved.

\section{Disaster Governance and 'Human Rights Based Approaches'}

In 2015, the UNHRC considered that the application of HRBAs to disaster management entails the application of the following principles, as derived from IHRL:

(i) Direct and intentional linkage to human rights;

(ii) Transparency; 
(iii) Participation and consultation of those affected and beneficiaries;

(iv) Non-discrimination;

(v) Special attention given to the needs of vulnerable and marginalized subgroups within the larger set of beneficiaries;

(vi) Accountability

(UNHRC, 2015, paras. 6-7, 9, 40, 95)

Although no single, conclusive definition of "HRBAs" exists - the element of transparency is not always included, for example (see Vandenhole \& Gready, 2014)all definitions of HRBAs include at least the five elements of '(intentional) linkage to human rights standards'/normativity', 'non-discrimination', 'empowerment/vulnerability', 'participation' and 'accountability' (Vandenhole \& Gready, 2014). Originally, the concept of HRBAs derives from the field of development cooperation, where it was predominantly aimed at encouraging states and international organizations/agencies to integrate IHRL standards into their development projects and programming. A highly detailed and instructive example of HRBAs to disaster management by UN agencies can be found in the Training Manual on 'Human Rights-Based Approaches to Programming' by the United Nations Population Fund (UNFPA), setting out step-bystep how human rights standards, including as clarified in other important standard-setting initiatives on disaster management, can be integrated in programme design by UNFPA Country Staff, implementing partners and others working in the same field (UNFPA, 2010). The Manual includes a full module on HRBAs in 'emergency response', which sets out how the abovementioned HRBA principles can or have been applied in specific case-studies. By now, HRBAs are commonly advocated to address various development-related problems, and can supposedly be applied by various actors, i.e. certainly by international organizations and NGOs, but also by businesses (see e.g. Vandenhole \& Gready, 2014).

The application of 'HRBAs' generally denotes two things: first, it emphasizes substantive human rights standards as a distinct way of normatively evaluating the quality of governance involved; second, it views relevant actors concerned as 'duty bearers' with concrete responsibilities to protect 'rights holders'. In fact, HRBAs uniquely serve an operational purpose in that they intend to provide duty bearers with clear standards and principles for the design, implementation and evaluation of programmes, projects and activities. Practically speaking, HRBAs require actors to fully understand, respect and protect applicable human rights of affected human beings when setting up and implementing new projects and plans; to engage and consult the disaster-affected or disaster-prone population through participatory mechanisms; to not discriminate when providing or securing access to relevant assistance or in setting up relevant recovery programmes, evacuation plans, zoning laws etc.; and to actively and continuously identify who is vulnerable, left out or needs extra help (e.g. rural populations, the elderly, handicapped, women, children or the poor) (see also Hesselman, 2013; Hesselman \& Lane, 2017; Kälin, 2011). The element of 'participation' speaks clearly to the complaint that MLG regimes may lack 'poor presence of citizens' representation', as it requires all stakeholders to engage affected populations in decisions affecting rights (UNHRC, 2015, para. 40(c)). Simply stated, securing 'accountability' requires that fora are identified or set up through which individuals can require relevant governance actors to be answerable for their decisions and conduct, and hold them to account for (potential) human rights violations, through sanction or reward. At the international level, HRBAs on the basis of IHRL directly open up recourse to relevant international accountability and oversight mechanisms with respect to states (Cubie \& Hesselman, 2015; UNHRC, 2015, para. 40(e)). As discussed in Section 4.1, the importance of accountability mechanisms for business actors or NGOs is acknowledged, but still requires further development. Finally, 'transparency' (in particular access to information) is linked to and improves the exercise of accountability by making visible what has been decided, coordinated or carried out (or not) (UNHRC, 2015, para. 40(f)).

Some limitations of HRBAs must be acknowledged, however; as further discussed below, IHRL has traditionally focused on states as the sole or primary duty bearer, and human rights treaties only legally bind these actors. Moreover, until recently, the interpretation of human rights standards took place mostly in relation to states' own behavior and responsibilities/obligations, although the following paragraphs will demonstrate that this is changing in some respects. Nevertheless, even the multiduty bearer approach (to be outlined in Section 4.2) would not necessarily envisage obligations for all relevant non-state actors, such as individuals in local communities, for example, who may be first responders or charged with DRR activity (see earlier mention of Aldrich \& Meyer, 2015). For instance, de Lourdes Melo Zurita et al. $(2015$, p. 392$)$ point out that in Australia individual households may be made responsible for protecting their property in case of bush fires under a nationally endorsed 'stay or go' policy, which raises the difficult but important question of how this affects the (human rights) responsibilities of the state for protecting these persons and their property, especially in case of failures by individuals or communities to carry out protective tasks; does this imply or affect human rights responsibility of these actors, or of states, or both? This could reduce HRBAs' ability to ensure accountability and protection within disaster governance.

In summary, HRBAs may prove a useful tool for a broad range of governing actors-including non-state actors such as NGOs or businesses-to ensure that their activities are jointly geared towards meeting important public interests, such as protecting persons in times of disaster. The role of HRBAs in guiding the distribution of disaster governance responsibilities in a MLG regime 
will be analyzed through the following examination of human rights responsibilities for non-state actors under HRBAs.

\subsection{HRBAs: Human Rights Responsibilities for Non-State Actors}

In essence, 'HRBAs' imply that 'plans, policies and processes...are anchored in a system of rights and corresponding obligations established by international law' (United Nations Office of the High Commissioner for Human Rights, 2006, emphasis added). This of course requires an understanding of the 'system of rights and corresponding obligations' that present IHRL establishes, whether for states or non-state actors.

Here, it is important to first clarify that traditionally, IHRL typically places legal obligations on states, and it considers states the principal international and national duty bearers. Yet, IHRL has recently been grappling with the observation that it would become 'less and less relevant if it fails to adapt to changing realities in which States are no longer the only leading actor' (Vandenhole \& van Genugten, 2015, p. 1). For this reason, IHRL has been responding to the challenges posed by non-state actors in several ways.

First, international human rights treaties have been evolutively interpreted in a way that states' duties were expanded to cover the human rights risks and violations emanating from non-state actors; more specifically, states are obliged to 'protect' individuals against such risks and violations within their territory or jurisdiction (see e.g. European Court of Human Rights, 2008). A great example of this obligation in the context of disasters is states' 'duty to regulate' the dangerous or polluting (industrial) operations of businesses, particularly by setting up adequate regulatory systems for facilities and operations involving permits, safety regulations, monitoring and providing for (criminal) accountability as necessary (CteeESCR, 2000, paras. 48, 51; European Court of Human Rights, 2008; Hesselman \& Lane, 2017; see generally Hallo de Wolf, 2011, pp. 242-245). IHRL also requires states to regulate relationships between individuals inter se, e.g. in the sense of safeguarding life or physical integrity, including as a matter of criminal law, although this has not gained full attention yet in the area of disaster management (see e.g. European Court of Human Rights, 1985, 2008, paras. 129-132).

Second, importantly, IHRL has also evolved to articulate direct, separate responsibilities for non-state actors themselves, i.e. alongside those of the state. Here, we do not speak about an extension of the state's own obligations, but of extra (complementary) obligations for others (Vandenhole \& van Genugten, 2015, p. 5).

The evolution of complementary responsibilities for business particularly occurred through the 2011 UN Guiding Principles on Business and Human Rights (UNHRC, 2011 [UNGPs]). This unique human rights instrument, endorsed by the UN Human Rights Council, affirmed in great detail that businesses have their own human rights responsibilities distinct from states (even if states also continue to bear their obligation to regulate the conduct of businesses). Human rights responsibility for corporations mostly requires businesses 'to do no harm', i.e. to operate in such a manner as not to interfere with individuals' existing human rights enjoyment (Hesselman \& Lane, 2017; UNHRC, 2011, Guiding Principle 11). One of the difficulties has been to determine when this obligation to 'do no harm' is triggered and how it applies exactly in and across business operations, since businesses are not, and should not, be involved in or made responsible for every aspect of human life or disaster governance. We therefore see that the 'business and human rights' community is currently further exploring the (legal) bases and concepts which can ground businesses' human rights responsibilities, including, for example, 'human rights in the supply chain' or '(spheres of) influence' (see e.g. Telesetsky, 2015). Similarly, pursuant to the UNGPs, this community is now concerned with further pursuing 'grievance mechanisms' to improve 'accountability' for business-related human rights violations, as well as exploring a new binding IHRL treaty on business and human rights (see UNHRC, 2011, Principles 25-31 on 'access to remedy').

A further interesting question is to what extent businesses or other actors, such as NGOs, also have a human rights responsibility 'to do good', i.e. to positively contribute to improved human rights protection where they can-e.g. by delivering aid to disaster victims (see Telesetsky, 2015). International human rights treaty supervisory bodies have considered in this regard that the role of the WHO, UNCHR, IFRC, UNICEF, as well as NGOs are considered of 'particular importance in relation to disaster relief and humanitarian assistance in times of emergencies'. Moreover:

[w]hile only States are parties to the [International] Covenant [on Economic, Social and Cultural Rights] and thus ultimately accountable for compliance with it, all members of society [including] intergovernmental and non-governmental organizations, civil society organizations, [and] the private business sectorhave responsibilities regarding the realization

of important disaster related human rights (CteeESCR, 2000, para. 42). Yet, the exact scope of positive obligations is difficult to determine. For example, for NGOs, there are hardly any further indications for their expected behavior, save for the practice of self-regulation (e.g. see Sphere Project, 2011, and an exception in UNHRC, 2015, para. 40(g)); more discussion in Hesselman \& Lane, 2017). The UNGPs have been criticized for not contemplating positive responsibilities at all. In the absence of clear (legal) responsibilities it may be difficult to try to hold private actors directly responsible for failure to contribute to improved human rights protection in disaster settings, although arguably this is increasingly 
addressed through self-regulatory activity (see for more discussion, Hesselman \& Lane, 2017; cf. Telesetsky, 2015, on the UN Global Compact). Of course, states' positive human rights obligations may lead them to incorporate horizontal responsibilities (owed between non-state actors, including between individuals) within domestic disaster law and policies (e.g. duties of care for others in emergency situations, or duties of healthcare professionals to respond to disasters-see e.g. American Nurses Association, 2010).

Before moving on to consider the emergence of 'multi-duty bearer human rights regimes', it is important to stress again that under no circumstances will a state be able to legally absolve itself of its own legal IHRL responsibilities, by delegation or through the emergence of new duties for other actors (Vandenhole \& van Genugten, 2015). The full responsibility for human rights protection as committed to under IHRL applies generally and cannot be replaced, legally delegated or changed through some type of out-sourcing (see Brownlie, 1994; Lane, 2016; Vandenhole \& van Genugten, 2015, p. 5). Instead, regulation by the state, as well as the establishment of any separate obligations for non-state actors, should be seen as attempts to try to govern human rights protection better or more completely/expansively (see Bell \& Hindmoor, 2009, p. 150).

\subsection{Multi-Duty Bearer Human Rights Frameworks}

The concept of 'multi-duty bearer human rights regimes' has arisen from concerns regarding the continued relevance and effectiveness of 'state-centred' IHRL in the present age, and it inspires a 'fundamental re-thinking of a basic tenet of human rights law', notably 'that human rights obligations are primarily incumbent on the territorial State' (Vandenhole \& van Genugten, 2015, p. 1). In fact, IHRL scholars suggest that '[h] uman rights law has to move beyond territoriality as the main criterion for assigning human rights obligations' (Vandenhole \& van Genugten, 2015, p. 1, emphasis added). Yet, the challenge is then, if duties are not 'assigned' on the basis of (state) 'territory', what is the basis for responsibilities instead? Here, it is useful to point out that IHRL in fact commonly supports both the concepts 'territory' and 'jurisdiction' as a basis for IHRL obligations, with the term 'jurisdiction' normally equated to exercising some type of 'effective control' over a territory, population or individual(s) (see De Schutter et al., 2012, pp. 1104-1109; United Nations Human Rights Committee, 1981, paras. 12.1-12.3). Perhaps here, the MLG literature discussed above can actually offer some inspiration to further conceptualize the notion of 'jurisdiction' in human rights law, e.g. as potentially involving both territory and 'specialization', or 'sphere of influence', or perhaps 'effective control' over important resources (De Schutter et al., 2012, p. 1154, e.g. referring to control over technologies). Inspiration from Type I MLG 'jurisdictions' in particular might suggest that human rights obligations can and should come about at different, nested 'territorial levels', alongside the state's territorial jurisdiction, e.g. for international organizations (such as the UN and its various organs carrying out its work) within their competences. On the other hand, the notion of Type II MLG jurisdictions may particularly inspire us to (also) consider how human rights responsibility can come about in a task-oriented manner, e.g. as based on unique 'expertise', 'resources' or 'skills' that actors have to offer, within their sphere of operation, influence or organizational mandate. In fact, the terms 'position', 'ability' or 'capacity' to assist are common terms in IHRL underpinning positive IHRL obligations for states and might be applied to others as well, such as businesses or NGOs-although across the board, there is still some difficulty delimiting when 'capacities' may have been exhausted exactly (see De Schutter et al., 2012, pp. 1150-1154; or Telesetsky, 2015, suggesting that companies should assist until the point of bankruptcy when state authorities cannot address disasters effectively themselves, which seems extreme).

In the 'multi-duty bearer human rights regimes' literature, several criteria or approaches have been suggested to (al)locate human rights responsibilities to/for non-state actors so far, including when non-state actors' activities could be considered: 'relevantly public' (publicness approach); necessary to offer effective human rights protection (functional approach); or when they (risk) adversely affect(ing) human dignity or human rights (stakeholder approach) (Vandenhole \& van Genugten, 2015 , p. 4). Following these grounds, most actors currently involved in disaster management could be considered relevant human rights duty bearers, and be called upon to consider IHRL standards and HRBAs seriously in their activities. In order to expedite the process of articulating human rights-based responsibility in a multi-duty bearer setting, and thereby of achieving greater joint protection of affected populations, this article agrees with Vandenhole and van Genugten $(2015$, p. 6) who support that successful multi-duty bearer regimes may have to embrace an active role for non-state actors themselves in carving out and clarifying their respective human rights obligations in specific settings. This would take place through self-regulation or co-regulation, and could greatly stimulate the legitimacy and acceptability of standards 'and hence the potential abidance by the rules' (Vandenhole \& van Genugten, 2015, p. 6). Although it is beyond the remit of this article to examine examples of human rights-based self- or co-regulation that exist already in the area of (sector-based) disaster governance (see Hesselman \& Lane, 2017), these practices certainly exist. Some examples include: the 'Guiding Principles for Public-Private Collaboration for Humanitarian Action' (prepared jointly by the World Economic Forum and the United Nations Office for the Coordination of Humanitarian Affairs, 2007), the Sphere Project's 'Humanitarian Charter and Sphere Minimum Standards in Humanitarian Response' (drafted by international NGOs and humanitarian organizations; Sphere Project, 2011), 
or 'Disaster Response: Guidelines for Establishing Effective Collaboration between Mobile Network Operators and Government Agencies', (drafted by GSMA, a telecom branch organization; GSMA, 2012).

\section{Conclusion}

MLG theory usefully sheds light on how 'disaster governance' is currently dispersed at the international, national and sub-national territorial levels of decisionmaking, and is simultaneously fragmented in 'a baroque patchwork' of highly task-specific governance communities that bring together many different public and private actors' specialized knowledge, expertise and resources (Marks \& Hooghe, 2004). This article considered whether/how better unity of action and purpose could be achieved in such highly dynamic, multi-level, multiactor governance landscapes, including a more coherent distribution of roles and responsibilities, especially from a perspective of IHRL and HRBAs.

We observed that IHRL emphasizes the 'primary role and responsibility' of the state in disaster governance and for human rights protection, but also increasingly seeks to account for the behavior of non-state actors. This includes affirming states' duty to adequately regulate risks and violations emanating from non-state actors. Yet, as governance literature also supports, the ever-growing participation of non-state actors in (disaster) governance reveals that states cannot provide, control or command all activities and resources necessary for adequate protection. Moreover, non-state actor activity may impact human rights enjoyment very directly, both negatively or positively. This raises the pertinent question of their direct human rights responsibilities, alongside and distinct from those of states. IHRL has certainly begun to respond to these concerns, inter alia, through the concept of 'multi-duty human rights bearer' regimes (Vandenhole \& van Genugten, 2015). The notion of multi-duty bearer regimes supports that, while an important regulatory, directive role/task and prerogative for states always remains-because states' duties to protect individuals cannot be abrogated-the delimitation of grounds for non-state actors' own responsibilities (including during disasters) is firmly underway. We argued that the (al)location of human rights responsibility could be highly assisted by improved application of HRBAs by relevant non-state actors, including through human rights-based self- or co-regulation (see also Hesselman \& Lane, 2017; Vandenhole \& van Genugten, 2015).

Ultimately, those affected by disasters have a right to benefit from adequate protection through appropriate, transparent and accountable disaster governance activities, which requires the concerted action of many different actors. This article has argued that adherence to IHRL in the form of HRBAs by all those involved can greatly improve the protection of persons through a better articulation of roles and responsibilities, and by emphasizing accountability for universal IHRL standards towards affected populations as a primary principle of organization. Finally, we also hope to have demonstrated, with an analysis seeking to draw simultaneously from governance literature and IHRL scholarship, that the field of 'disaster governance' is not just a multi-level and multiactor affair, but also lends itself to broader multi-, or inter-disciplinary analysis.

\section{Conflict of Interests}

The authors declare no conflict of interests.

\section{References}

Aldrich, D. P., \& Meyer, M. A. (2015). Social capital and community resilience. American Behavioral Scientist, 59(2), 254-269.

American Nurses Association. (2010). Who will be there? Ethics, the law, and a nurse's duty to respond in a disaster. Retrieved from http://www.nursingworld.org/ MainMenuCategories/Policy-Advocacy/Positions-and -Resolutions/Issue-Briefs/Disaster-Preparedness.pdf

Bache, I., Bartle, I., \& Flinders, M. (2016). Multilevel governance. In C. Ansell \& J. Torfing (Eds.), Handbook on theories of governance (pp. 486-498). Cheltenham and Northampton: Edward Elgar.

Bartle, I., Bache, I., \& Flinders, M. (2012, June). Rethinking governance: Towards convergence of regulatory governance and multilevel governance? Paper presented at the ECPR Standing Group on Regulation and Governance 4th Biennial Conference, University of Exeter, UK.

Bell, S., \& Hindmoor, A. (2009). Rethinking governance: The centrality of the state in modern society. Cambridge: Cambridge University Press.

Brownlie, I. (1994). State responsibility: The problem of delegation. In K. Ginther, G. Hafner, W. Lang, H. Neuhold, \& L. Sucharipa-Behrmann (Eds.), Völkerrecht Zwischen Normativem Anspruch und Politischer Realität (pp. 300-330). Berlin: Duncker \& Humblot.

Cubie, D., \& Hesselman, M. (2015). Accountability for the human rights implications of natural disasters: $A$ proposal for systemic international oversight. Netherlands Quarterly of Human Rights, 33(1), 9-41.

De Lourdes Melo Zurita, M. L., Cook, B., Harms, L., \& March, A. (2015). Towards new disaster governance: Subsidiarity as a critical tool. Environmental Policy and Governance, 25, 386-398.

De Schutter, O., Edie, A., Khalfan A., Orellana, M., Salomon, M., \& Seiderman, I. (2012). Commentary to the Maastricht principles on extraterritorial obligations of states in the area of economic, social and cultural rights. Human Rights Quarterly, 34, 1084-1169.

European Court of Human Rights. (1985). $X$ and $Y v$. The Netherlands, Application no. 8978/80, Judgment of 26 March, 1985.

European Court of Human Rights. (2008). Budayeva and others v. Russia, Applications nos. 15339/02, 
21166/02, 20058/02, 11673/02 and 15343/02, Judgement of 20 March 2008.

Farber, D. (2014). International law and the disaster cycle. In D. Caron, M. Kelly, \& A. Telesetsky (Eds.), The international law of disaster relief (pp. 7-20). Cambridge: Cambridge University Press.

Fisher, D. (2007). International disaster relief: A growing regulatory dilemma. Proceedings of the Annual Meeting of the American Society of International Law, 101, 114-118.

Gall, M., Cutter, S. L., \& Nguyen, K. (2014). Governance in disaster risk management. IRDR AIRDR Publication No. 3. Beijing: Integrated Research on Disaster Risk.

Graham, J., Amos, B., \& Plumptre, T. (2003). Principles for good governance in the 21st Century (Policy Brief No. 15). Retrieved from http://iog.ca/wp-content/ uploads/2012/12/2003_August_policybrief15.pdf

GSMA. (2012). Disaster response: Guidelines for establishing effective collaboration between mobile network operators and government agencies. Retrieved from http://www.gsma.com/mobilefordevelopment /wp-content/uploads/2013/01/Guidelines-for-Estab lishing-Effective-Collaboration.pdf

Hallo de Wolf, A. (2011). Reconciling privatization with human rights. Antwerp: Intersentia.

Hesselman, M. (2013). Establishing a full 'cycle of protection' for disaster victims: Preparedness, response and recovery according to regional and international human rights supervisory bodies. Tilburg Law Review, 18(2), 106-132.

Hesselman, M., \& Lane, L. (2017). Disasters and nonstate actors-Human rights-based approaches. Disaster Prevention and Management. Manuscript in preparation.

Hooghe, L., \& Marks, G. (2003). Unraveling the central state, but how? Types of multi-level governance. The American Political Science Review, 97(2), 233-243.

Inter-Agency Standing Committee. (2011, January). Operational guidelines on the protection of persons in situations of natural disasters. Retrieved from http://www.ifrc.org/docs/idrl/1922EN.pdf

International Disaster Response Law' Programme of the International Federation of the Red Cross. (2000). World disasters report. Retrieved from www. ifrc.org/Global/Publications/disasters/WDR/9000-W DR2000.pdf

International Disaster Response Law' Programme of the International Federation of the Red Cross. (2007). Law and legal issues in international disaster response: A desk study. Retrieved from http://www.ifrc. org/PageFiles/125639/113600-idrl-deskstudy-en.pdf

International Law Commission. (2016). Protection of persons in the event of disasters (Draft Articles) (Un Doc. A/CN.4/L.871). Retrieved from http://legal. un.org/docs/?symbol=A/CN.4/L.871

Jones, S, Oven, K. J., Manyena, B., \& Aryal, K. (2014). Governance struggles and policy processes in disas- ter risk reduction: A case study from Nepal. Geoforum, 57, 78-90.

Kälin, W. (2011). A human rights-based approach to building resilience to natural disasters. The Brookings Institution. Retrieved from http://www.brookings. edu/research/a-human-rights-based-approach-to-bu ilding-resilience-to-natural-disasters

Lane, L. (2016). Private providers of essential public services and de jure responsibility for human rights. In M. Hesselman, A. Hallo de Wolf, \& B. Toebes (Eds.), Socio-economic human rights in essential public service provision (pp. 139-159). London: Routledge.

Levi-Faur, D. (2012). From big government to big governance. In D. Levi-Faur (Ed.), The Oxford handbook of governance (pp. 3-15). Oxford: Oxford University Press.

Marks, G., \& Hooghe, L. (2004). Contrasting visions of multi-level governance. In I. Bache \& M. V. Flinders (Eds.), Multi-level governance (pp. 15-30). Oxford: Oxford University Press.

May, P. J., \& Williams, W. (1986). Disaster policy implementation: Management strategies under shared governance. New York, NY: Plenum Press.

Papadopoulos, Y. (2007). Problems of democratic accountability in network and multilevel governance. European Law Journal, 13(4), 469-486.

Peters, B. G., \& Pierre, J. (1998). Governance without government? Rethinking public administration. Journal of Public Administration and Theory, 8(2), 223-243.

Rhodes, R. A. W. (2006). The new governance: Governing without government. Political Studies, 44(4), 652-667.

Rosenau, J. N., \& Czempiel, E.-O. (Eds.). (1992). Governance without government: Order and change in world politics. Cambridge: Cambridge University Press.

Sphere Project. (2011). Humanitarian charter and minimum standards in humanitarian response. Retrieved from http://www.ifrc.org/PageFiles/95530/The-Sph ere-Project-Handbook-20111.pdf

Stephenson, P. (2013). Twenty years of multi-level governance: 'Where does it come from? What is it? Where is it going?'. Journal of European Public Policy, 20(6), 817-837.

Stone, D., \& Ladi, S. (2015). Global public policy and transnational administration. Public Administration, 93(4), 839-855.

Telesetsky, A. (2015). Beyond voluntary corporate social responsibility: Corporate human rights obligations to prevent disasters and to provide temporary emergency relief. Vanderbilt Journal of Transnational Law, 48, 1003-1027.

Tierney, K. J. (2012). Disaster governance: Social, political, and economic dimensions. Annual Review of Environment and Resources, 37, 341-363.

United Nations Committee on Economic, Social and Cultural Rights. (2000). General comment No. 14: The right to the highest attainable standard of health (Art. 12 of the Covenant) (E/C.12/2000/4). Retrieved from 
http://tbinternet.ohchr.org/_layouts/treatybodyext ernal/Download.aspx?symbolno=E\%2fC.12\%2f2000 $\% 2 f 4 \&$ Lang=en

United Nations Human Rights Committee. (1981). Sergio Euben Lopez Burgos v. Uruguay, Communication No. R.12/52.

United Nations Human Rights Council. (2011). Report of the Special Representative of the Secretary-General on the issue of human rights and transnational corporations and other business enterprises, John Ruggie (A/HRC/17/31). Retrieved from http://www.ohchr. org/documents/issues/business/A.HRC.17.31.pdf

United Nations Human Rights Council. (2015). Final research-based report of the Human Rights Council Advisory Committee on best practices and main challenges in the promotion and protection of human rights in post-disaster and post-conflict situations (A.HRC/28/76). Retrieved from http://reliefweb.int/ sites/reliefweb.int/files/resources/A_HRC_28_76_ en.pdf

United Nations Office for Disaster Risk Reduction. (2015a). Global assessment report on disaster risk reduction. Retrieved from http://www.preventionweb. net/english/hyogo/gar/2015/en/gar-pdf/GAR2015_ EN.pdf

United Nations Office for Disaster Risk Reduction. (2015b). 2015-2030 Sendai Framework for Disaster Risk Reduction, adopted by Third UN World Conference on Disaster Risk Reduction (A/CONF.224/CRP.1). Retrieved from http://www.unisdr.org/files/43291 _sendaiframeworkfordrren.pdf
United Nations Office for Disaster Risk Reduction. (2017). Terminology on DRR. The United Nations Office for Disaster Risk Reduction. Retrieved from http:// www.unisdr.org/we/inform/terminology

United Nations Office for the Coordination of $\mathrm{Hu}$ manitarian Affairs. (2017). Cluster coordination. Retrieved from http://www.unocha.org/what-we-do/ coordination-tools/cluster-coordination

United Nations Population Fund. (2010). A human rightsbased approach to programming: Practical information and training manuals. Retrieved from http:// www.unfpa.org/resources/human-rights-based-app roach-programming

United Nations Office of the High Commissioner for Human Rights. (2006). Frequently asked questions on a human rights-based approach to development cooperation (UN Doc HR/PUB/06/8). Retrieved from http://www.ohchr.org/Documents/Publications/FAQ en.pdf

Vandenhole, W., \& Gready, P. (2014). Failures and successes of human rights-based approaches to development: Towards a change perspective. Nordic Journal of Human Rights, 34(2), 291-311.

Vandenhole, W., \& Genugten, van, W. (2015). Introduction: An emerging multi-duty-bearer human rights regime? In W. Vandenhole (Ed.), Challenging territoriality in human rights law: Building blocks for a plural and diverse duty-bearer regime (pp. 1-12). Abingdon: Routledge.

\section{About the Author}
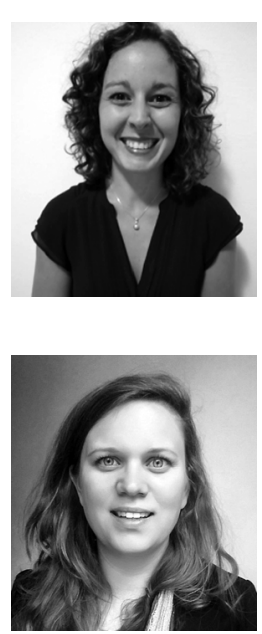

Lottie Lane, LLM, is a PhD Candidate at the Endowed Chair, Groningen Centre for Law and Governance. Her PhD research deals with the horizontal effect of human rights at the international, regional and national levels from a law and governance perspective. Lottie's wider research interests and publications include the human rights responsibilities of non-State armed groups, business and human rights, and the role of human rights and non-State actors in disaster governance.

Marlies Hesselman, LLM, is a Lecturer in International Law and finishing a PhD in international human rights law at the University of Groningen. Marlies' research interests and publications relate to international disaster law, socio-economic human rights law, business and human rights, energy and climate and sustainable development law. 